\title{
Pollinating insects (Hymenoptera: Apoidea, Apiformes) as an example of changes in fauna
}

\author{
Józef BANASZAK \\ Institute of Environmental Biology, Kazimierz Wielki University, 12 Ossolinskich Av., 85-093 Bydgoszcz, Poland; \\ e-mail: lednica@ukw.edu.pl
}

\begin{abstract}
Changes in the Apiformes fauna are discussed on the basis of the fauna of Poland and other European countries, starting from historical times. The presentation of contemporary changes accounts for different trends: (a) population decline or disappearance of some species (shrinking ranges), (b) population increases or expansion of other species. The fauna is described dynamically against the background of environmental change (fluctuation hypothesis). It is postulated that updated comprehensive studies of faunal resources need to be undertaken, concentrating on species diversity and density.
\end{abstract}

Key words: bees, wild bees, bumble bees, honey bees, Apiformes, changes in fauna, species extinction, species expansion, permanence of fauna, Bialowieża Primeval Forest.

\section{INTRODUCTION}

Along with climate warming, the dying of species and decreas in population are the most popular research areas investigated by environmental biologists. The literature on pollinating insects also abounds in publications on this topic. These publications, however, are not always based on reliable data.

Some of these works mentioned by the readers were under the impression that writing and talking about species extinction is "the in thing". Now, some authors are desperately looking for evidence of this process. Sometimes the evidence is far from convincing, or present catastrophic visions without the required scientific rationale. This is more surprising as our knowledge about the fauna, even in most European countries, is incomplete. Faunal changes have certainly been taking place everywhere and at all times. However, in order to be reliable, their interpretation should involve an appropriate time and place perspective. Regrettably, much is still to be done in this respect.

It should be remembered that as a result of the intensive development of ecology and experimental biology after World War 2, faunal studies (or faunistics) were treated condescendingly, or even despicably, by some naturalist communities. Poland is one of the good example in this case. Today, studies of the fauna and flora are slowly winning back favour, partly because of, as it were, a surfeit with ecological studies but also because of the recent "run" on biodiversity, the concept being also part of the EU strategy.

A number of apidologists have investigated faunal changes in numerous publications, to mention Changes in fauna of wild bees in Europe with J. Banaszak as editor (1995), where authors from various European countries presented examples of the disappearance or population declines in certain species. Another publication worthy of mention is the proceedings of a National Scientific Conference (Olsztyn, 21-23 September 2002) under the characteristic title Ochrona owadôw w Polsce - ekologiczne i gospodarcze konsekwencje wymierania $i$ ekspansji gatunków [Insect protection in Poland - ecological and economic consequences of species extinction and species expansion] (Czachorowski \& Buchholz 2002). 
Faunal changes against the background of changes in flora on a regional scale are discussed in the book Stepowienie Wielkopolski - pót wieku później [Steppe transformation of Wielkopolska - half a century later] (Banaszak 2003), the title referring to the once-famous Stepowienie Wielkopolski [Steppe transformation of Wielkopolska] edited by Prof. Adam Wodziczko (1947). Local changes in wild bee fauna have been traced by Banaszak in 10-year cycles since the 1970s (Banaszak 1997, Banaszak et al. 2003).

The decline of honey bee populations is a separate and very important problem. In the 1980s several studies investigated the parasite Varroa destruktor Anders a. Truem., and since the middle of the present decade the pages of bee-keeping journals have been bursting with reports of a dramatic decrease in the population of honey bees in the world as a result of a mysterious phenomenon known as the colony collapse disorder (CCD) or the extinction of feral colonies (Wilde 2009a).

The extent, rate and directions of faunal changes are of cardinal importance for contemporary apidology. Optimistically, the status of and changes in fauna have been widely, even globally, addressed by the International Pollinators Initiative: The São Paulo Declaration on Pollinators (1998), a breakthrough document in the history of apidology in the world placing on apidologist entomologists an obligation to undertake research on the fundamental problems of wild bees and honey bees. The European Pollinator Initiative is the European response to the São Paulo declaration. In an attempt to address the current needs of apidology the FAO Working Group on Pollination and Pollinator Diversity Management was formed in the mid-1990s. Pollinator insects in the world were also the topic of the International Symposium for the Conservation and Sustainable Use of Pollinators, held during the $21^{\text {st }}$ International Congress of Entomology in Brazil in 2000. During that meeting, I presented the main points of my report The state of pollinators in Europe and strategy for their protection (the full texts of this and other reports have regrettably not been published), and a similar report was read by me at the Sixth European Bee Conference in Cardiff (Banaszak 2002b). Various aspects of changes in invertebrate fauna, including bees, are also presented in my paper entitled Zagadnienia zmian fauny bezkręgowców [Problems of changes in invertebrate fauna] (Banaszak 2003). The following text is generally based on these presentations, but it also draws on newer studies and ideas as a number of new publications on the fauna of Poland have appeared since those articles and papers were written, most notably the work on Białowieża Primeval Forest (Banaszak \& Jaroszewicz 2009), which sheds new light on the development of the fauna of Poland. The present article thus takes a broader look on faunal changes, doing so also from a historical point of view.

\section{THE DEVELOPMENT OF BEE FAUNA (IN POLAND) IN HISTORICAL TIMES}

The present state of the fauna is the result and consequence of changes in landscape that have been taking place at least since Mediaeval times, when man began to create radical changes in the landscape. The main interfering factors have been the reduction in forest areas, chiefly as a result of the development of agriculture and settlement, the birth of large cities and, ultimately, transportation.

One thousand years ago, nearly $25 \%$ of the area of Poland was arable fields and orchards, with meadows and pastures representing approximately 10\% (Kostrowicki 1965). Towards the end of the Middle Ages, about 50\% of Poland was used for agricultural purposes, including $12 \%$ occupied by meadows and pastures. The three-field rotation was prevalent then, as it was until the mid-19 $9^{\text {th }}$ century (Zareba 1986). Massive deforestation was noted particularly from the 14 th century onwards, when timber rafting to Western European countries became common. The main reason behind clear felling of forests was the development of towns and cities, but 
the ship-building industry also enhanced demand for the timber. The burning of wood to obtain potash was another destructive form of forest management. Intensely managed forests were pushed increasingly farther away from towns and settlements. Nowadays, forests occupy about $28 \%$ of the area of Poland and are not evenly distributed. The current situation is thus the opposite of that in the Middle Ages, with forests' share similar to that of Mediaeval arable fields and orchards.

Since the Middle Ages, the then-dominant forest landscape has regularly given way to open areas - agricultural land and urban areas.

The honey bee Apis mellifera L. was an original and constant element of the forest entomofauna. The presence of the honey bee in Central Europe dates back to the period following the last glaciation, when forests began to enter our land. The history of the honey bee in the area bordered by the Oder in the west and the Vistula and Bug in the east dates back to at least eight thousand years ago (Budzyńska 2005), but not more than ten thousand years ago (Skowronek 1997). Age-old trees in ancient primeval forests provided favourable conditions for honey bees, which settled in numerous natural tree hollows. Later, people learned to carve artificial hollows and place bees in them (forest bee-keeping). This practice continued at least from Mediaeval times until the 18th/19th century, when the honey bee was finally "driven" out of wooded areas and into apiaries on farms. From then on, bees came to be only a temporary component of the forest biocoenosis at times when they were taken into forests to feed on heather or honeydew. The departure of the honey bee from primeval forests and woods undoubtedly had an effect on these biocoenoses, including other wild bees competing for the same food, such as bumble bees and solitary bees.

Man's beekeeping thus first increased Apis mellifera populations and later led to their decline. From the $16^{\text {th }}$ until the end of the $18^{\text {th }}$ century a forest would contain several to several dozen thousand trees used for bee-keeping. In Bory Tucholskie, for example, the number could reach 20,000 (Wróblewski 1991), and the government-owned forests at the time of Congress Poland had over 17,000 bee-keeping hollows (Blank-Weissberg 1937). Bialowieża Primeval Forest contained 4,500 registered bee-keeping hollows as late as the $17^{\text {th }}$ century, of which one thousand were active (Banaszak in press).

Ultimately driven out of forests in the 19th century, the honey bee began to enrich the agricultural landscape and, from then on, was only occasionally taken back into forests. At the same time, the shrinking areas of increasingly younger managed forests did not offer favourable conditions for "feral" honey bees that could survive without the help of man. Thus, over approximately 500 years man influenced the forest biocoenosis twice by manipulating honey bee populations. It is now legitimate to ask how these practices affected or might have affected other wild bees? Some light has been shed by recent research on Apiformes fauna in the Białowieża National Park (Banaszak \& Jaroszewicz 2009). The study presents the contemporary fauna of the forest, which has survived intact through the centuries. Owing to the primeval character of the Białowieża forest, today's data on species diversity and dominance patterns can be extrapolated to the fauna that could inhabit it in the Middle Ages, while comparative studies of the contemporary bee fauna of Bialowieża and the (so much transformed) rest of the country show the directions of changes that have taken place over hundreds of years.

At present, Bialowieża National Park is home to 146 species and the entire Polish part of Białowieża Primeval Forest supports 182 species. These numbers are comparable to those recorded for other lowland national parks or other territorially close areas. However, there are cardinal differences in the species composition and dominance of the most numerous species. In terms of the abundance of bee families, apart from the honey bee, which used to be a 
permanent component of the biocoenosis and probably a dominant, today's eudominant is he white-tailed bumble bee Bombus lucorum, accounting for $30.9 \%$ of all species there. This species is a clear dominant in all three main forest types in Bialowieża. Bombus lucorum individuals also account for more than $71 \%$ of all Bombus bees in Białowieża Primeval Forest. Other bumble bee species, including those most numerous in the other regions of Poland, namely Bombus pascuorum and Bombus lapidarius, are much less numerous here. This is the dominance pattern in the Bialowieża Primeval Forest of today and so it could be centuries ago, inasmuch as the forest has preserved its primeval character. The patterns of dominance among bumble bees in Białowieża and elsewhere in Poland are presented in Figure 1. With the shrinking of forests and the expansion of agricultural landscape, the role (proportion) of $B$. lucorum (L.) has decreased with a concomitant rise of other species, especially the related bufftailed bumble bee Bombus terrestris (L.) and the red-tailed bumble bee Bombus lapidarius (L.) and the ubiquitous common carder bee B. pascuorum (Scop.) (Fig. 1a).
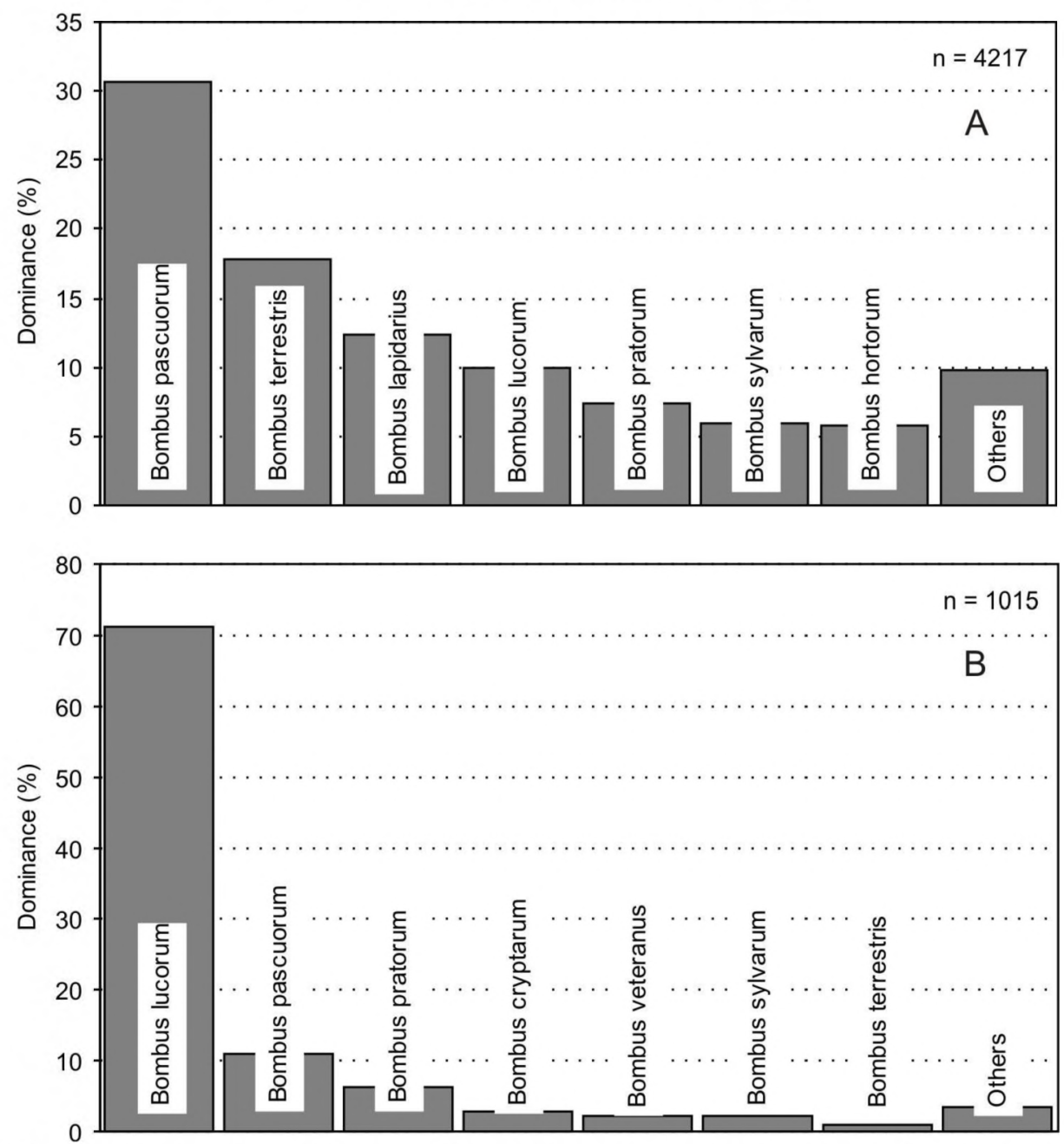

Fig. 1. Dominance patterns in bumble bee populations of different biotopes (meadow/forest) in the Polish Lowlands A (Banaszak \& Motyka 2007) and in Białowieża Primeval Forest - B (Banaszak \& Jaroszewicz 2009). 
The spread of open agricultural landscapes inevitably spurred off another process: the influx into Poland of steppe-associated open-area species coming from regions south west of today's Polish borders or from German refuges in the West. These expansions used river valleys or the Moravian Gate in the south to spread, as was demonstrated in an earlier paper (Banaszak et al. 2006). Changes in the bee fauna in response to decreasing afforestation are well illustrated in Figure 2.

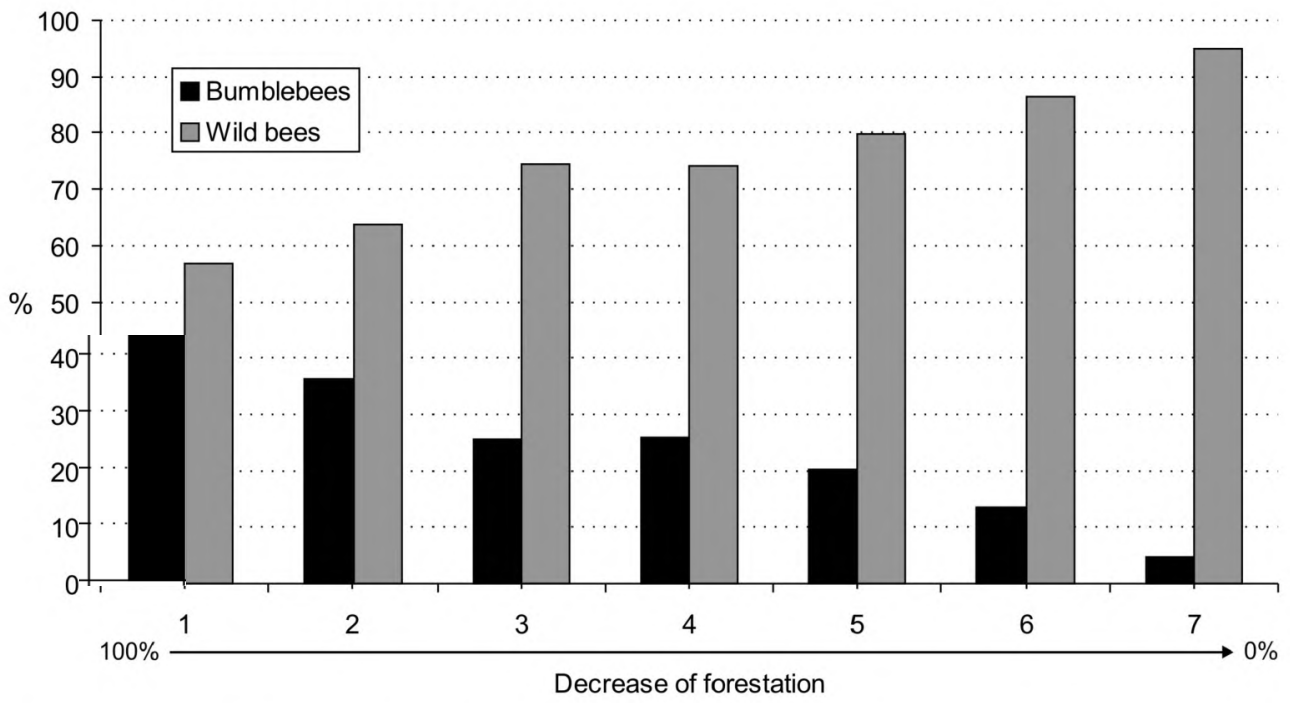

Fig. 2. Comparison of the contribution of bumble bees and other wild bees by landscape afforestation rate 1 Białowieża Primeval Forest (Banaszak \& Jaroszewicz 2009), 2 - Drawa NP. (Banaszak et al. 2009b), 3 - Bory Tucholskie NP. (Banaszak \& Wendzonka 2002), 4 - Wigry NP (Banaszak \& Krzysztofiak 1996), 5 - Central Poland (Banaszak \& Kowalczyk 2007), 6 - Narew NP. (Banaszak 2006), 7 - xerothermic swards in the Lower Vistula (Banaszak et al. 2006).

The decreasing forest cover in Poland that followed the development of agriculture and settlement gave rise to two opposite processes: the decrease in the numbers of bumble bees and an increase in the proportion of other wild bee species, particularly the halictids.

The above review, though rather superficial, clearly shows what transformations have occurred in the pollinator fauna over the last few centuries:

- the proportion of honey bee was increased in Mediaeval primeval forests;

- the honey bee was driven out of forests in the 19th century, thus increasing its share in the agricultural landscape;

- the patterns of dominance among bumble bees in forests changed;

- open-area fauna was able to freely penetrate into the area of Poland from other parts of Europe;

- ultimately over at least 500 years the pollinator fauna in Poland was thoroughly transformed. These transformations have been effected by man. Thus, faunal changes are not only a phenomenon seen in the contemporary era.

\section{THE PERMANENCE AND CURRENT STATUS OF FAUNA}

Before discussing present-day changes in fauna, which are only being recognised, it is worthwhile to reflect on faunal permanence. The survival of fauna is documented in increasingly numerous inventories, catalogues, as well as red lists and books, which are 
published in most countries today. Polish readers can browse the Wykaz Zwierzat Polski [Polish Fauna Inventory], edited by J. Razowski (1990-1997), or a series of catalogues of Polish fauna.

The diversity of the European Apiformes fauna may be regarded as the best studied. The overall number of bee species described from Europe amounts to 1,500-1,600 species, with estimates from different authors ranging between 1,100 and 1,500. Estimates of 1,500 or above should be regarded as very realistic (Banaszak 2002a). We owe these data to the dozens of faunal researchers carrying out their laborious studies for more than 200 years. Thanks to these studies, the species compositions of bees have been identified, to a greater or smaller extent, nearly in all European countries and individual regions in these countries.

Of note, faunal studies concerning Apiformes were already very advanced in the early 20 th century. In 1909, Friese listed the following species numbers for particular countries and regions: 200 species for Great Britain, 200 for Sweden, 380 for Tirol, 440 for Germany, and 510 for Hungary. The estimate provided by this arguably greatest expert on European apians ever for the entire continent was 2,000 species (Guglia 1969). I do not think he was much mistaken. It is interesting to see the species figures given for individual regions in central European countries. In Germany, for example (Stoeckhert 1933, 1954), 443 species have been recorded in Francony, 399 in Baden, and 340 in Saxony.

Table 1. Number of species of wild bees in European countries (Banaszak 2002b, supplemented)

\begin{tabular}{|c|c|c|c|}
\hline Country & $\operatorname{Area}\left(\mathrm{km}^{2}\right)$ & Number of species & Author \\
\hline Ireland & 84.400 & 102 & Fitzpatrick et al. 2006 \\
\hline Norwey & 323.895 & 125 & Loken, unpubl. data \\
\hline Denmark & 43.069 & 217 & Jõrgensen 1921 \\
\hline Great Britian & 244.755 & 250 & O'Toole \& Raw 1993 \\
\hline Finland & 337.032 & 273 & Vikberg 1986 \\
\hline Luxembourg & 2.586 & 274 & Rasmont et al. 1995 \\
\hline Sweden & 449.790 & 278 & Janzon et al. 1991 \\
\hline Lithuania & 65.200 & 322 & Monsevicius 1995 \\
\hline Belgium & 30.507 & 376 & Rasmont et al. 1995 \\
\hline Poland & 312.685 & 474 & Banaszak 2004 \\
\hline Slovenia & 20.750 & 536 & Gogala 1999 \\
\hline Germany & 356.840 & 547 & Schwarz et al. 1996 \\
\hline Switzerland & 41.285 & 580 & Schwarz et al. 1996 \\
\hline Austria & 83.855 & 647 & Schwarz et al. 1996 \\
\hline Czech Republic & 78.900 & 584 & Straka et al. 2007 \\
\hline Slovakia & 49.000 & 643 & Straka et al. 2007 \\
\hline Ukraine & 603.700 & 700 & Osytshnjuk 1970 \\
\hline Romania & 237.500 & 850 & Iuga 1958 \\
\hline France & 551.208 & 865 & Rasmont et al. 1995 \\
\hline Italy & 301.245 & 944 & Pagliano 1995 \\
\hline Spain & 504.880 & 976 & Ceballos 1956 \\
\hline Central Europe (Austria, Germany, Switerland) & 481.980 & 728 & Schwarz et al. 1996 \\
\hline Western Europe & 658.039 & 913 & Rasmont et al. 1995 \\
\hline Former USSR & 571.000 & 1000 & Osytshnjuk 1970 \\
\hline Europe & $10,529.000$ & 1571 & \\
\hline
\end{tabular}


Species lists for regions of Poland are similarly rich, with 271 species in Central Pomerania (Alfken 1912), 273 in West Pomerania (Blüthgen 1919, 1942), 320 in Wielkopolska-Kujawy Lowland (Torka 1913, 1933, Banaszak 1987), 315 in Silesia (Dittrich 1903), and 274 in Małopolska (Loziński 1920). These regions each have an area comparable to that of Belgium. Such faunal richness should be attributed both to the considerable landscape diversity of these areas and to the possible high proportions of diverse zoogeographical elements, northern as well as southern.

Contemporary studies, particularly those carried out in the $1990 \mathrm{~s}$, have resulted in the compilation of a number of species lists of Apoidea from different European countries. The species diversity of Apoidea in Europe is illustrated in Table 1. These data testify to the permanence of the fauna irrespective of local scale changes.

Since Krzysztof Kluk's book (Kluk 1802), about 400 publications on the Apiformes (not including the genus Apis) have been published in Poland. Despite this large number of works, data on the species composition and distribution of Polish bees are incomplete. The main reason is differences in the completeness of data from different regions and also the fact that in the case of many species basic information is mostly contained in papers written a hundred years ago. Many species recorded in the more distant past need to be re-confirmed as extant. Old and new sources together account for a total of 474 species recorded from the territory of Poland (Banaszak 2004).

Some light is also shed on the issue of faunal permanence by a comparison of studies of Apoidea in the Wielkopolska-Kujawy Lowland in western Poland carried out by Torka in the early $20^{\text {th }}$ century (Torka 1913) and Banaszak in the 1970s (Banaszak 1983, 1987). It must be noted that both studies meet criteria underlying the validity of such comparisons: 1) the areas of study overlap considerably; 2) the areas are large enough (approx. 20,000 $\mathrm{km}^{2}$ ); 3) the studies were carried out over many years, thus reliable data could be recorded for the entire bee fauna. The comparison reveals the absence of significant qualitative changes in the Apoidea of Wielkopolska-Kujawy Lowland over the 50 years, despite the traditionally intensive agricultural management in the area. Torka's inventory from the early 20 th century lists 270 species and the list provided by Banaszak fifty years later contains a similar number of species (258). Apart from the numerical difference of a dozen or so species, there are also other differences between the two lists. Each inventory contains a rather large number of species not found in the other list, though most of these are rarely recorded. Many of these have an insular distribution in the study area and are therefore very difficult to find. The presence of some was confirmed only after several years of intensive search. Of the combined total of 320 species, 208 were found by both authors. The contemporary study failed to confirm the presence of 63 species which were recorded by Torka as single specimens and which can still be found in neighbouring areas but are rarely recorded there. Perhaps identifying them in Wielkopolska is a question of time. This possibility is borne out by the finding, in the contemporary list of Apoidea in Wielkopolska, of 39 species not recorded by Torka, these also being rare species. Interpreting the differences between the lists as not indicating the failure of the respective authors to find certain species does not seem to be well-founded.

A closer look at the two lists leads to an important conclusion regarding dominance patterns in bees in the study area. In Torka's times, faunal research involved collecting all specimens of rare and less abundant species, but only some specimens of numerous or common species, thus providing an approximation of relative abundance, though the subjectivity of this kind of assessment did play a role. The species defined as "frequent" and "very frequent" by Torka are still among those most often encountered today, on the basis of which it may be concluded that the dominance patterns in bee assemblages have remained pretty much the 
same. In summary, in this region of good farming traditions resulting in extensive anthropic pressure, the Apoidea fauna may have been numerically reduced, though the intensity of these changes is difficult to estimate at present. As regards qualitative changes, no significant changes of this type were recorded until the 1980 s or at least no convincing evidence exists to postulate that such changes did occur. Research currently under way may provide a final explanation. For several years, the present author has been intensively searching the very sites that Torka worked on nearly a hundred years ago.

Catastrophic visions of faunal dying out can be countered with examples that confirm faunal permanence as well as high abundance. Studies of Apoidea in Lednica Landscape Park near Gniezno revealed large abundances of these insects, with mean densities above 1,000 individuals per hectare. It should be noted that on the Ostrów Lednicki island on Lednica Lake, the abundance of bumble bees reached level rarely registered elsewhere, with 900-1,500 individuals per hectare recorded in the spring (Banaszak 1996). A similar example of a bee fauna faring well locally is the density of wild bees in a xerothermal sward on Dziadek Lake in Piska Forest. In July 2000 this figure reached over 8,000 (sic!) individuals per hectare, half of which were bumble bees, and the rest were mainly composed of Anthophora bimaculata! (Banaszak 2003). It should be added that these sites are free from crop-boosting chemicals.

\section{CONTEMPORARY TRANSFORMATIONS OF FAUNA}

\section{Disappearance of fauna - the myths and the facts}

Faunal extinction myths. A review of existing literature on the bee superfamily Apoidea shows, however, that along with reports of actual faunal changes that have been objectively analysed, there are generalisations and conclusions that are unduly rash or at least doubtful. Species extinction myths are growing stronger for a number of reasons, including those listed below.

1. Inadequate knowledge of species distribution, especially those species that are rarely encountered outside their continuous ranges, and rash conclusions drawn from isolated findings. Faunal studies have usually been carried out in the region of authors' residence; thus the areas of study have usually been small.

2. Almost complete lack of data regarding Apiformes density in natural and near-natural habitats. Attempts to obtain such data using objective methods have only started recently, i.e. in the 1970 s.

3. Fishing for examples to support the recently fashionable theory of faunal change. Let us use an example from western Poland (Wielkopolska). When, in the mid-20th century, naturalists realised the degradation of the environment due to over-desiccation of soil, following tree felling, excessive land improvement practices and regulation of river flow, faunists added to these genuinely true observations their own isolated examples, not always aptly chosen, to illustrate an influx of xerophilous fauna. Stepowienie Wielkopolski (Wodziczko 1947) includes three chapters on faunal transformations presenting as decreases in the abundance of particular species with the concomitant emergence or increases in the abundance of other species. This is discussed, among others, by Sokolowski (1947) and Szulczewski (1947).

Szulczewski (1947) offers a rather detailed treatment of the degradation of Wielkopolska, which assume to be the reason for the changes in invertebrate faunas. Over-desiccation of the region, writes Szulczewski, is the aftermath of actions of the Prussian administration continuing from at least the late 19th century and involving forest felling, river regulation, destruction of oxbow lakes and meanders where water was present until July and flooded 
agriculturally managed meadows, drainage of wetlands, and improvement (drainage) of fields by numerous land improvement companies forming from the year 1880 onwards.

For the aforementioned reasons, Szulczewski goes on to present the consequences of these actions, involving changes in the flora such as: the disappearance of plants more sensitive to moisture deficits, decreased seed production in plants (even resistant pines produced, according to the author, fewer cones) and reduced numbers of mushrooms in forests, the influx of xerophilous plants (30 "recent newcomers" were noted in Poznań in 1930).

The 24 invertebrates listed are equally divided into those disappearing or manifesting reduced abundance and those classified as expansive or recorded for the first time and considered migrants from warmer and drier areas. The researchers list overdrying and deforestation as well as degradation of the environs of towns and cities as the causes of these changes. These factors encouraged the influx of thermo- and xerophilous fauna and withdrawal of forest species. These data merit a comment. It seems as if Szulczewski, just like Sokołowski, is trying to find evidence to support the popular and quite spectacular steppe-transformation theory. The examples given by Szulczewski pertain to a very diverse range of animal taxa, and this taxonomic over-diversity makes them a rather superficial illustration of the phenomenon rather than fool-proof evidence. At the same time, all his examples pertaining to Aculeata are inappropriate, due to his inadequate awareness of the taxonomy and zoogeography of this group. None of the species he lists can be regarded as an example of, as the author wishes it to be, the penetration of "southern migrants" into Wielkopolska. The species (Halictus wenkowiczi [shouldn't that actually be Melitta wankowiczi Radoszkowski?], Alysson perthesi Gorski, Hedychridium flavipes Eversm., Coelioxys polycentris Förster, Eoferreola thoracica (Rossi), Stizus fasciatus F.) were either wrongly determined or the author did not know their actual distribution. These inadequacies were pointed out by the best Polish expert on this insect group, Prof. J. Noskiewicz (1939-1948a).

It should also be stressed at this point that Szulczewski did not avoid regrettable shortcoming also in another work of his regarding the bees of Wielkopolska National Park, which also happened to be the first source of data on this fauna in that national park (Szulczewski 1948). The author listed two species that are non-existent in the apiological literature: "Andrena costulata Kriechb". and "Andrena fulvipes Panz.", and his "Halictus sexnotatulus" was probably Lasioglossum sexmaculatum (Schenck), an error also pointed out by J. Noskiewicz (1939-1948b). Let us also add that a review of the Polish collections of Halictidae revealed that the percentage of misattributed specimens sometimes reached $30 \%$ or more! Researchers sometimes avoid verifying their collections, as a result of which their publications actually deserve to be called unreliable. This problem has been discussed, among others, by Pesenko et al. (2000, p. 81).

4. Species were wrongly determined not only in the past. Bee experts are still hard to come by. Most countries currently have up to two or three biologists with a fairly good knowledge of bees, and this equally applies to Poland.

5. More detailed contemporary faunal studies confirm that some species previously considered extinct are actually extant in Poland (Banaszak 2002a).

6. Inappropriate methodology of abundance analysis can lead to odd conclusions. One example of that is the sensational reports of Dylewska (eg. 1990, 1997) stating that the current Polish population of bumble bees numbers less than $1 \%$ (sic!) of the population from the 1960s. This is based on a complete misunderstanding of the principles for estimating species abundance, including the concept of sample size.

7. Decreases in populations of bees (including bumble bees) have been attributed to the increased use of chemicals in agriculture, though I am not aware of any studies that 
actually confirm or refute this thesis, for example in Poland. At the same time no-one speaks out about how many rare and easily captured species might have disappeared as a result of amateur captures. The most probable cause of disappearance of the only Polish colony of Chalicodoma muraria Retz. was excessive capturing by an amateur collector.

Examples of population decreases or disappearance of species. Data on threats to European Hymenoptera are rather fragmentary and difficult to obtain. An accurate balance of threats is not available. The main source of information is the IUCN list of endangered species, based on regional or national Red Lists. The content of the list may be alarming as one can find there 960 out of the 12,000 European species known to science, or about $8 \%$, the rate being even higher for some groups (Collins 1987, Gauld et al. 1990).

By the end of the 1980s, we had no data on threats to Hymenoptera from most European countries. The above statement notwithstanding, it should be generally admitted that some EU countries have implemented wide-ranging programmes to restore extinct insect species and monitor them. The leading countries with regard to insect protection are the United Kingdom, the Netherlands or France. The European Union issues, under the auspices of the Council of Europe, publications devoted to the protection of species and ecosystems. Of these publications, at least two have been concerned with Hymenoptera (numbered in order of publication), No. 44 "The biological significance and conservation of Hymenoptera in Furope 1990" and No. 61 "Towards the conservation of aculeate Hymenoptera in Europe 1991." Austria, Belgium, Germany and the United Kingdom have contributed the most towards the compilation of the Hymenoptera Red List. The main species found in existing Red Lists have been compiled by Day (1991), who did not include lists from non-EU countries. Collins \& Wells (1987) present an overview of the legislation related to endangered species and their identification.

The Polish Red List on bees contains 222 species (47.3\%), but one half of these are species rarely observed and usually poorly studied. Twenty-two species $(5.5 \%)$ are regarded as threatened in Poland, and $18(3.8 \%)$ have not been recorded in Poland for at least 50 years (Banaszak 2002a).

The last two decades have brought numerous reports of decreasing populations of wild Apiformes among various local faunas in Europe (eg. Day 1991, O'Toole 1993, 1994; Williams 1982, 1986, 1989; Rasmont et al. 1993, Rasmont, Terzo 1996; Pekkarinen 1999). Recently, there have also been alarming news about decreases in the populations of some species of bumble bees, particularly in Western Europe and the U.S.A. (Goulson et al. 2005, 2008; Darvill et al. 2006). The proceedings of an international conference on changes in the bee fauna have been published in the book "Changes in Fauna of Wild Bees in Europe" (Banaszak 1995).

Cierzniak (2003) evaluated changes in the Apoidea fauna of Wielkopolska National Park in western Poland. Out of the total 226 species, 44 have not been currently confirmed (19.4\%), but most of these species are recorded in neighbouring areas, which means that any disappearance of these bees is local in character.

Undesirable changes in wild bee populations are as follows

- the extinction of particular species in some countries in the case of small isolated populations outside of the continuous range (eg. Chalicodoma muraria in Poland);

- decreasing abundance in areas exposed to a particular type of pressure;

- the withdrawal of certain species from particular areas (regions of countries), for example as a result of afforestation or other practices or pressures, eg. ecological successions in swards.

These changes mainly affect specialist species, i.e. long-tongued (eg. 40\% in Belgium) and oligolectic (eg. in Finland). The scale and extent of changes varies with the location and pressure intensity. Existing data show that decreasing abundance, increased threats or extinction may affect up to $8-10 \%$ of the total population in Poland. 
The causes of regression of wild bees given by apiologists are diverse and include:

a - intensified agriculture and the associated decrease in diversity, by pesticide poisoning of wild bees and other factors;

b- landscape fragmentation and reduction of bee survival sites (Williams 1989, O'Toole 1994);

c - structural simplification of the agricultural landscape (Banaszak 1983);

$\mathrm{d}$ - simplification of crop structure - Corbet et al. (1991) state that the food resources of bees are being reduced as a result of changes in the agricultural landscape where intensive farming has led to the emergence of "sterile fields and their environs", with no perennial or biennial plants;

e - changes in land use structure, eg. in Finland, natural meadows and pastures now occupy only a fifth of the area they occupied one hundred years ago. The growing of trees in meadows and pastures as a result of succession and afforestation decreases the area of nesting sites and the food base, especially in the case of oligolectic species (Pekkarinen 1999). The area decrease of flower-rich grasslands, and the associated reduction in previously abundant Fabaceae, which are a particularly important source of food for long-tongued bees, including bumble bees (Goulson et al. 2005);

$\mathrm{f}-$ mineral fertilisation of meadows and the consequent changes in plant composition, for example the disappearance of bees' host plants and the expansion of grasses (Kosior 1987, Goulson et al. 2005);

$\mathrm{g}$ - the disappearance of old clay buildings from the rural landscape has deprived several species of nesting sites (Banaszak 1970). This is especially the case with Anthophora plagiata (J11.). In Central European conditions, this species probably became synanthropised, using as its nesting sites clay walls which offered better conditions than natural escarpments in a wet and cooler climate. Now many old rural buildings have been demolished and with this $A$. plagiata has withdrawn, at least from the Polish Lowlands (Banaszak 2003, W. A. Banaszak 2005).

Since the 1980s there has been a distinct decline in Polish bee keeping. In the early 1990s it was estimated that there were still about a million honeybee colonies, raised by approximately 100,000 beekeepers. That represented a decrease of about $40 \%$ compared to the mid-1980s (Gromisz 1995). The causes included both unfavourable economic conditions (Pidek 1991), and a dangerous parasitic disease of bees caused by the mite Varroa destuctor Anders. et Truem. At the end of 1998, there were only 780,000 registered honeybee colonies and the number of beekeepers had decreased to 48,000 . Such a drastic decrease in the numbers of honeybee colonies had previously been seen during the war and occupation, when the number of honeybee colonies decreasing by half from 1,450,000 in 1939 to 750,000 in 1945 .

In the years 1992-1996 the number of honeybee colonies in European Union countries grew by $6.4 \%$, with an accompanying significant increase of $10.8 \%$ in the number of people professionally involved in beekeeping as an alternative source of income. Today the beekeping world is facing a new challenge. The mysterious Colony Collapse Disorder (CCD) has killed an immense number of families (Gliński 2007). The disease is attributable to a group of factors, including chemicals, Varroa mites, other parasites and fungi, IAPV virus, and GMO. The extent of the problem can be illustrated by US honeybee colonies losses, estimated at between 750,000 and one million honeybee colonies (2007-2008). Some beekeepers have reported losses of 90\% (Cox-Foster \& van Engelsdorp 2009).

The beekeeping crisis in Poland and as well as in the world has intensified since 2006, when professional beekeepers first reported losses of up to $90 \%$. The condition of beekeeping is decisive for the crops of more than 80\% plant species grown in Europe. In the UE the value of pollination is estimated at approximately 153 billion euro a year. In February 2008 the 
European Commission ordered EFSA to investigate bee mortality and its causes in the EU (Święcicki 2009, Wilde 2009b).

The reduction in numbers of honey bee families chiefly affects the possibilities for pollinating orchards. The absence of bees may predominantly limit orchard planning. The unprecedented fall in the number of apiaries, also in Poland, is not only a problem for beekepers but is becoming a challenge in terms of the conservation of species and nature in Poland in general. A deepening crisis in beekeeping may bring about unpredictable consequences for the economy of man and nature.

A separate problem related to the purity of domestic honey bee breeds is the unlimited import of alien breeds into our country and the absence of limitations on their cross-breeding with domestic bees.

Genetic protection of honey bee populations is of general ecological importance as a component of efforts to save the dying out forms within the species of Apis mellifera. Endangered local bee populations should therefore be included in conservation plans.

Examples of population growth and expansion of species. Despite self-evident examples of dwindling numbers of local populations or the withdrawal of certain species from particular areas, one should still not speak of a general regression of bees as while some species are decreasing their numbers, other species preserve their ranges of occurrence and numbers and are also expansive. This disparity is well illustrated by a study of bumble bees and cuckoo bumble bees carried out in Cracow in 2000-2003, where the total of 28 species studied showed three disparate trends. After 1850 , ten species were regarded as undergoing severe regression, 11 were considered stable and 7 were actually classified as expansive (Kosior et al. 2008). Paradoxically, the range of some species may be shrinking in one country and expanding in another. This has been the case with Bambus veterenus $(\mathrm{F}$.), which is undergoing severe regression in Belgium and is markedly expansive in Finland (Pekkarinen et al. 1981). According to Rasmont, 39 (10.8\%) of the Belgian Apiformes species are expansive (Rasmont et al. 1993). The author also listed 5 representatives of Apoidea whose numbers have grown since 1950, namely, Bombus pratorum (L.), B. hypnorum (L.), Psithyrus sylvestris Lep., Psithyrus norvegicus Sech., and Ps. bohemicius (Seidl.).

It should be stated that, generally, there are examples of: a) permanence of a fauna despite pressures, b) expansion of some species c) re-discovery of species regarded as lost following more insightful research. This last issue is certainly known to every researcher. Polish examples have included the rather spectacular re-discoveries of representatives of the genus Xylocopa: $X$. valga Gerstaecker and $X$. violacea (L.). Both of these southern species are among the least rarely recorded wild bees, which is associated with the fact that the northern limits of their ranges are in Poland. Both can be found in the Polish Animal Red List: Xylocopa valga is a CR (critically endangered) species, and $X$. violaceae is classified as probably extinct (EX?) (Banaszak 2004). $X y l o c o p a$ valga has been recorded extremely rarely in the post-war period, and $X$. violacea has been registered again after a period of 75 years. However, after 2000, both species have been registered on several occasions in south-eastern Poland (Banaszak \& Piotrowski 2005; Banaszak \& Sołtyk 2005, Banaszak et al. 2008, Banaszak et al. 2009a; Banaszak \& Zięba 2009). The question arises whether both species were present in Poland as small and isolated populations throughout that time and went unnoticed by researchers (though they are definitely hard to overlook) or, perhaps, they appear periodically? The continuity of occurrence is supported by existing records of Xylocopa valga, while the +70 -year gap in records of $X$. violaceae may indicate a re-influx of this species into Poland. Perhaps it is associated with climatic changes, observed since the mid-1980s.

Other positive examples include the case of Andrena fulva (Müller), which can now be seen nesting in often huge colonies, for example, in city parks in Western Europe and in western Poland, including Poznań (Banaszak 1994). 


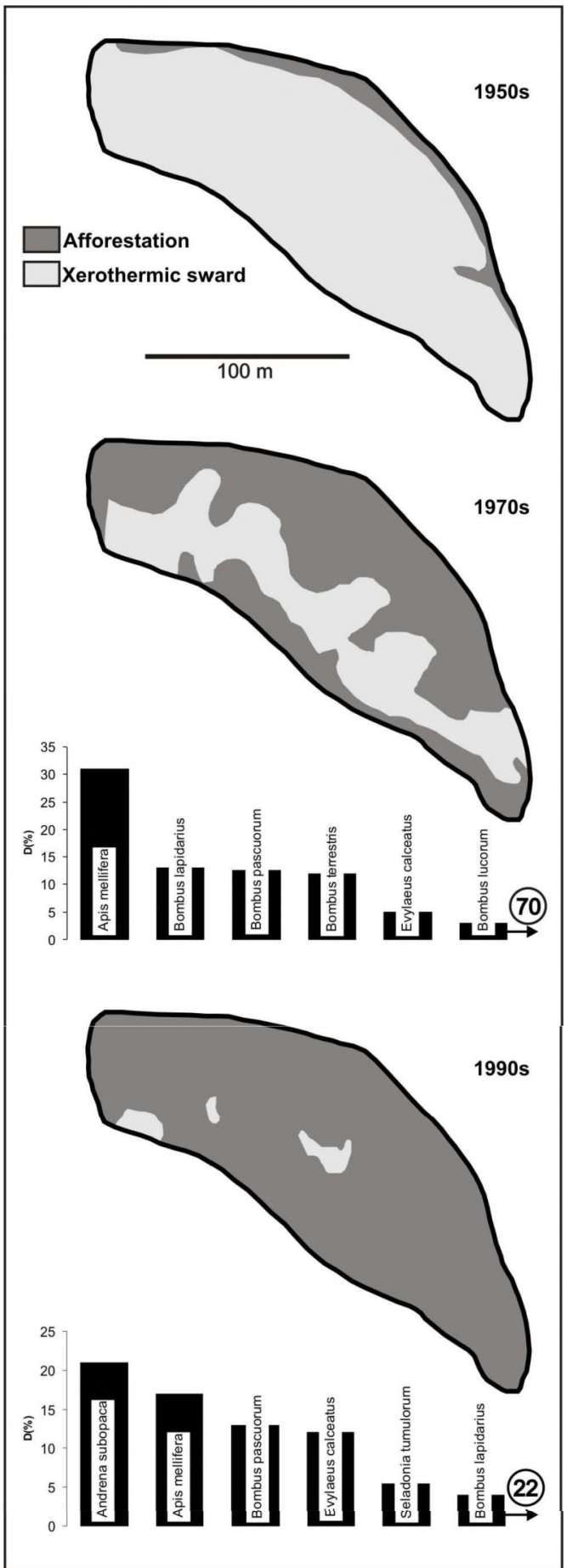

Fig. 3. Example of environmental change caused by ecological succession and leading to changes in bee fauna (Cierzniak et al. 2005).
This Andrena does not actually mind heavy traffic in the city and the soil and air pollution. On the other hand, Torka (1913) recorded only one male specimen of this species in western Poland. Andrena fulva, formerly known from western Poland and never seen to cross the Vistula, has recently been found also in the east of the country (Banaszak 2003). This is undoubtedly a sign of eastern expansion of this western species.

Bombus semenoviellus Skorikov has been registered in Poland since the mid-1990s (Plewka 1995, Kowalczyk 1997). Analysis of the distribution of this species shows that this bumble bee species is quickly spreading westwards and southwards and has also been recorded all over Poland (Banaszak, data on file), and also in the Czech Republic (Straka et al. 2007) and Germany (Smissen \& Rasmont 1999, Franke-Mauss - oral communication).

Since the mid-1970s Banaszak has been studying changes in pollinator faunas at permanent study sites set up in two landscape types: a natural landscape in Wielkopolska National Park (two strips of forested land and a xerothermal sward) and an agricultural landscape in General Dezydery Chłapowski Landscape Park (road side, poplar alley, shelter belt). Data obtained to date reveal stable faunas at most sites, possibly with a tendency to increase both their species diversity and density. A distinct fall in the number of bee species and density has been registered solely in the xerothermal sward and has been associated with it being overgrown by trees (Banaszak 1997, Banaszak et al. 2003).

Changes in fauna - a consequence of scale and time, the fluctuation hypothesis. Both the clear examples of decreasing populations of wild bees and the finding of some species that are expanding attest to faunal variability, at least variability of some part of fauna. It seems natural as the fauna responds to the effect of human economic activity. This is inevitable. This activity can have a negative effect, reducing faunal resources, but other times it can be beneficial, 
as when host plants are grown in large areas, such as rape, clover, alfalfa, etc. The diversity of wild bee species may also be stimulated by moderate habitat fragmentation, as illustrated by suburban zones, which are not uncommonly richer in fauna than dense areas of forests and meadows (Cierzniak 1995, 2003; Pawlikowski 1987). The state of a fauna today is thus the effect of diverse forms of human activity and natural succession processes operating in a given area. Studies indicate the presence of certain compensatory factors that reduce the impact of economy and other forms of human activity on populations of wild bees. Landscape-oriented studies of Apiformes ecology have identified the beneficial effect of such factors as, primarily, landscape mosaic in a system including an arable field and a faunal refuge (Banaszak 1983). Arable fields are, on the one hand, areas subjected to considerable pressures that preclude (or very much reduce) permanent occupation of fields by bees, but they can also be a virtually unlimited source of food (eg. a plantation of rape). On the other hand, faunal refuges, i.e. field margins, boundary strips, road sides, or in-field clumps of trees, are sites where populations of bees inhabiting agricultural landscapes can survive. Such systems may undergo certain changes, particularly quantitative, that are, however, less noticeable and probably regionally insignificant, as has been shown for the Wielkopolska-Kujawy Lowland. It appears that at least some reports of faunal transformations, perceived as undesirable changes, i.e. local depletion of fauna, should be interpreted in terms of faunal relocations within compensatory systems in agricultural landscapes. This approach has led to a hypothesis proposing the existence of regional-scale faunal fluctuations rather than progressive decreases in the population of wild bees (Banaszak 1983).

The question of scale and duration of faunal change posed in the heading above can be responded to by stating that faunal change should always be analysed with regard to both these factors. Faunal change is the result of various processes in the habitat, including both ecological succession and the inevitable impact of human activity.

The intensity of these changes and their extent in time are, however, a function of scale. Local changes stemming from the disappearance or transformation of microhabitats lead to the extinction or decrease of any population in the same scale.

In a fragmented landscape inhabited by a metapopulation of a species, local populations arise and disappear in the course of recolonisation. Overinterpreting local faunal changes may be dangerous. Let us quote an example. The southern slopes of an esker overlooking Budzyńskie Lake in Wielkopolska National Park were covered by a rich psammophilous sward described by Celiński \& Balcerkiewicz (1973) even in the 1960s. This small area (only 0.5 ha) was the site of a study of pollinating insects in the 1970s, during which 70 Apoidea species were identified. At present the slopes are nearly fully covered with ash maple and pine and the sward has been reduced to small remnants. Studies of bees in the 1980 s showed only 47 species on the slopes of the esker (Banaszak 1997), and now only 22 bee species can be found there (Banaszak et al. 2003). Apart from the radical decrease in species numbers, there dominance patterns have also changed (Fig. 3). Still, can this example underscore the catastrophic conclusion of progressive faunal extinction in Wielkopolska? The problem of overgrowing of swards and the consequent faunal changes on a national scale certainly merits further comprehensive study.

\section{KEY RESULTS AND CONCLUSIONS}

Man has changed the environment since historical times and, in this way, has influenced the fauna. Over the last few centuries, the fauna of pollinating insects has undergone multidirectional and major transformations:

- The proportion of honey bees was increased in Mediaeval primeval forests; 
- The honey bee was driven out of forests in the 19th century, thus increasing its proportion in agricultural landscape;

- The dominance patterns of bumble bees in forests have been changed;

- Open-area fauna has been able to freely penetrate into Poland (from other parts of Europe). The last 50 years have also brought reports of faunal change consisting in decreased populations of some species or expansion of other species. The fragmentary nature of the data means that the alarming phenomenon of declining bee populations requires comprehensive research with the aim of producing a detailed balance of faunal losses, but also faunal gains, in each country. Thus, there is an urgent need to evaluate natural resources (diversity and density) in natural and anthropogenic habitats using an objective and tested method all over our country, e.g. transects method (Banaszak 1980).

Further landscape-oriented studies of pollinator insect ecology are necessary. Effective conservation of species involves the protection of entire landscapes as well as ecosystems, for extinction in a protected area (in an ecosystem) is closely dependent on processes taking place outside.

With habitat changes, faunal changes occur inevitably due to both natural factors (ecological succession, climate change, fires) and the activity of growing human populations. All we can do is establish ways of realistic assessment of the scale, rate and directions of these changes. The problem lies in the incompleteness of our knowledge of these threats and changes. Existing studies are only preliminary and fragmentary, so they are far from being complete. It is the lack of knowledge about a phenomenon that induces the greatest fear. Only through detailed study will appropriate actions and solutions be found. Reports of faunal impoverishment had better be interpreted in terms of fluctuations of local faunas. And despite disappearance of certain species in the microscale or decrease in the abundance of others, much more dangerous is the limited scope of our knowledge of these phenomena. The solution to this troublesome situation, which urgently requires action, is to carry out systematic global research on present-day resources (diversity and density) of bees in a continuous manner (monitoring).

\section{REFERENCES}

ALFKEN J. D. 1912. Die Bienenfauna von Westpreussen. Bericht. Westpreussischen. Botanisch-Zoologischen Verein 34: 1-96.

BANASZAK J. 1970. Spostrzeżenia nad fauną błonkówek (Hymenoptera) glinianych ścian zabudowań wiejskich w środkowej Wielkopolsce. Badania Fizjograficzne nad Polską Zachodnia, Ser.B, 23: 231-233.

BANASZAK J. 1980. Studies on methods of censusing the numbers of bees (Hymenoptera, Apoidea). Polish Ecological Studies $6(2)$ : $355-366$.

BANASZAK J. 1983. Ecology of bees (Apoidea) of agricultural landscape. Polish Ecological Studies 9 (4): 421-505.

BANASZAK J. 1987. Fauna of wild bees (Hymenoptera, Apoidea) of Wielkopolsko-Kujawska Lowland during the last fifty years. Badania Fizjograficzne nad Polską Zachodnia, Ser. C, 36: 67-77. [In Polish with English summary]

BANASZAK J. 1994. Contribution to the biology and ecology of Andrena (Andrena) fulva (Müller, 1766) (Hymenoptera, Apoidea). Polskie Pismo Entomologiczne 63: 169-182.

BANASZAK J. (ed.) 1995. Changes in fauna of wild bees in Europe. Pedagogical University, Bydgoszez, 220 pp.

BANASZAK J. 1996. Wstępne wyniki badań nad zasobami naturalnymi owadów zapylających w Lednickim Parku Krajobrazowym. Studia Lednickie, Lednica-Poznań, 4: 495-498.

BANASZAK J. 1997. Local changes in the population of wild bees. I. Changes in the fauna ten years later. Ochrona Przyrody 4: 119-130.

BANASZAK J. 2002a. Apoidea Pszczoly. In: GıowACnNski Z. (ed.), Czerwona Lista Zwierząt Ginących i Zagrożonych w Polsce. Red List of Threatened Animals in Poland. Wydawnoctwo Instytutu Ochrony PAN, Kraków, 69-74.

BANASZAK J. 2002b. The problem of changes in bee fauna - a question of time or scale. In: JONES R. (ed.), Proceedings of the Sixth European Bee Conference, pp. 106-121. International Bee Research Association, Cardiff, X+162 pp.

BANASZAK J. 2003. Zagadnienie zmian fauny bezkręgowców. Prawda i mity na przykładzie owadów zapylających. In: BANASZAK J. (ed.), Stepowienie Wielkopolski - pół wieku później. Wydawnictwo Akademii Bydgoskiej im. Kazimierza Wielkiego, Bydgoszez, 101-116.

BANASZAK J. (ed.) 2003. Stepowienie Wielkopolski - pół wieku później. Wydawnictwo Akademii Bydgoskiej im. Kazimierza Wielkiego, Bydgoszez, 266 pp. 
BANaszak J. 2004. Apoidea In: Bogdanowicz W., Chudzicka E., PாIPIUK I. \& SkibLiska E. (eds), Fauna of Poland characteristics and checklist of species. Vol 1, pp.346-350. Muzeum i Instytut Zoologii PAN, Warszawa, 509 pp.

BANASZAK J. 2006. Bees (Hymenoptera: Apiformes) in the Narew National Park. Polskie Pismo Entomologiczne 75: $511-537$.

BANASZAK J. 2010. Pszezoly i lasy. Pszczoła miodna na tle polodowcowej historii lasów w Polsce. Wydawnictwo Wilczyska Maciej Rysiewicz, Wilczyska \& Wydawnictwo ,Alegoria”, Warszawa (in press).

BANASZAK J. \& KRZYSZTOFIAK A. 1996. The natural Wild resources (Hymenoptera: Apoidea) of the Wigry National Park. Polskie Pismo Entomologiczne 65: 33-50.

BANASZAK J. \& Wendzonka J. 2002. Bees (Hymenoptera: Apoidea) of the Bory Tucholskie National Park (NW Poland). Polskie Pismo Entomologiczne 71: 327-350.

BANASZAK J., CIERZNIAK T. \& RATYŃSKA H. 2003. Local changes in population of wild bees (Hymenoptera: Apoidea): 20 years later. Polskie Pismo Entomologiczne 72: 261-282.

BANASZAK J. \& PIOTROWSKI W. 2005. Two very rare Polish bee species Xylopa valga Gerstaecker and $X$ violacea (L.) in the Polesie National Park. Wiadomości Entomologiczne 24 (2): 77-80. [In Polish with English summary]

BANASZAK J. \& SOŁtYK D. 2005. Rare wild bee Xylocopa valga Gerstaecker, 1872 in Ojcowski National Park (Hymenoptera: Apoidea. Przegląd Zoologiczny 49 (3-4): 141-143. [In Polish with English summary]

BANASZAK J., CERRZNIAK T., KRTGER R. \& WENDZONKA J. 2006. Bees of xerothermic swards in the lower Vistula valley: diversity and zoogeographic analyses (Hymenoptera: Apoidea: Apiformes). Polskie Pismo Entomologiczne, 75: 105-154.

BANASZAK J. \& KowALCZYK J. K. 2007. Notes on bees (Hymenoptera: Apoidea: Apiformes) of central Poland. Fragmenta Faunsitica 50 (1): 1-18.

BANASZAK J. \& MOTYKA E. 2007. Diversity of bumblebee (Bombus Latreille, 1802) and cuckoo-bumblebee (Psithyrus Lepeletier, 1833) species in chosen nature reserves in northern Poland. Parki Narodowe i Rezerwaty Przyrody 26 (2): 75-92. [In Polish with English summary]

BANASZAK J., MELCZAREK L. \& NOWAK C. 2008. New localities of solitery bee Xylocopa violacea (Linnaeus, 1758) (Hymenoptera: Apiformes) In Poland. Wiadomości Entomologiczne 27 (1): 37-38. [In Polish with English summary]

BANASZAK J., MitKowsKi M. \& MKOEAJCZYK K. 2009a. New localities of two very hymenopterans in Poland: Parnopes grandior (Pallas, 1771) and Xylocopa valga Gerstaecker, 1872 (Aculeata: Chrysididae and Apidae). Polish Journal of Entomology 78: 111-113.

BANASZAK J., KRIgER R. \& CIERZNIAK T. 2009b. Bees (Hymenoptera: Apoidea, Apiformes) of the Drawa National Park. Polish Journal of Entomology 78 (2): 135-156.

BANASZAK J. \& JAROSZEWICZ B. 2009. Bees of the Bialowieża National Park and adjacent areas, NE Poland (Hymenoptera: Apidea, Apiformes). Polish Journal of Entomology 78 (4): 281-313.

BANASZAK J. \& ZIEBA P. 2009. The following localization of solitery bee Xylocopa violacea (Linnaeus, 1758) (Hymenoptera, Apoidea) In Poland. Wiadomości Entomologiczne, 28 (1): 63-64. [In Polish with English summary]

BANASZAK W. A. 2005. What has caused the decline of the solitary bee Anthophora plagiata (Illiger, 1806) (Hymenoptera: Apidea) in the Wielkopolska-Kujawy Lowland in West Poland? Polskie Pismo Entomologiczne 74: $157-185$.

BLANK-WEISSBERG S. 1937. Barcie i klody w Polsce. Polskie Towarzystwo Zootechniczne, Warszawa, 104 pp.

BLÜTHgen P. 1919. Die Bienenfauna Pommerns. Stettiner Entomologische Zeitung 80: 65-131.

BLÜTHGEN P. 1942. Die Bienenfauna Pommerns. Stettiner Entomologische Zeitung 103: 81-91.

BUDZYŃSKA M. 2005. Ochrona czarnej pszczoly Apis mellifera mellifera L. w pólnocnej Europie. Przegląd Pszczelarski 1: 25-28.

CELINSKI F. \& BALCERKIEWICZ S. 1973. Zespoly muraw psammofilnych w Wielkopolskim Parku Narodowym pod Poznaniem. Prace Monograficzne nad Przyrodą Wielkopolskiego Parku Narodowego 4 (5): 1-31.

Cebaltos G. 1956. Catalogo de los Himenopteros de España. Trabejos del Instituto Español de Entomologia, Madrid, $554 \mathrm{pp}$.

CIERZNIAK T. 1995. The effect of a differentiation of an agricultural landscape on Apoidea communities. Zeszyty Naukowe WSP, Studia Przyrodnicze 11: 13-50.

CIERZNIAK T. 2003 Changes in the bee fauna (Apoidea) of the Wielkopolska National Park over the last half century. Fragmenta Faunistica 46: 151-170.

CIERZNIAK T., RATYNisKA H., BANASZAK J. \& KACZMAREK L. 2005. Wplyw ochrony ścisłej na murawę kserotermiczną oraz faunę pszczół na przykładzie ozu nad Jeziorem Budzyńskim (Wielkopolski Park Narodowy). Przegląd Przyrodniczy XVI, 3-4: 53-83.

Collins N. M. 1987. Legislation to conserve insects in Europe. The Amateur Entomologist's Society 13: 1-80.

COLLINS N. M. \& WELLS S. M. 1987. Invertebrates in need of special protection in Europe. Nature and Environment Series 35. Council of Europe. Strasbourg, $162 \mathrm{pp}$.

CORBET S. A., WILliams L. H. \& OsBorne J. L. 1991. Bees and the pollination of crops and wild flowers in the European Community. Bee World 72 (2): 47-59.

CoX-Foster D. \& VAN ENGELSDoRP D. 2009. Na ratunek pszczolom. Przegląd Pszczelarski 2(15): 8-14. 
CZACHOROWSKI S. \& BUCHHOLZ L. (ed.) 2002. Ochrona owadów w Polsee - ekologiczne i gospodareze konsekwencje wymierania i ekspansji gatunków. Ogólnopolska Konferencja Naukowa, Olsztyn, 21-23 września 2002. Polskie Towarzystwo Entomologiczne, Poznań, Uniwersytet Warmińsko-Mazurski, Olsztyn, 64 pp.

Darvill B., Ellis J. S., LyE G. C. \& GoUlson D. 2006. Population structure and inbreeding in a rare and declining bumblebee, Bombus muscorum (Hymenoptera: Apidae). Molecular Ecology, 15: 601-611.

DAY M. C. 1991. Towards the conservation of aculeate Hymenoptera in Europe. Nature and Environment Series, $\mathrm{N}^{\circ} 51$, Council of Europe Press $44+$ XXXIII pp.

DITTRICH R. 1903. Verzeichnis der bisher Schlesien aufgefundenen Hymenopteren. 1. Apidae. Zeitschrift für Entomologie 28: 21-54.

DyLEwSKA M. 1990. Badanie nad zmianami fauny pszczół Apoidea w Ojcowskim Parku Narodowym po roku 1976. Prądnik. Prace Muzeum im. W. Szafera 2: 107-110.

DyLewsKa M. 1997. Trzmiele (Bambus Latr.) i trzmielce (Psithynts Lep.) Parków Narodowych Ojcowskiego i Świętokrzyskiego. Ośrodek Doradztwa Rolniczego, Karniowice, 10 pp.

FitzPatrick U., MURRay T. E., ByrNe A., PAXTON R. J. \& BROWN M. J. F. 2006. Regional red list of Irish bees. HEA, Queen's University Belfast.

Gatld I. D., ColtnNs N. \& FITTON M. G. 1990. L'importance biologique et la conservation des hymenopteres en Europe. Council of Europe, Strasburg $52 \mathrm{pp}$.

GLIŃSKI Z. 2007. Zespół CCD (Colony Collapse Disorder) nową chorobą pszczoły miodnej. Przegląd Pszczelarski 3 (8): $31-32$.

GOGALA A. 1999. Bee Fauna of Slovenia: Checklist of species (Hymenoptera: Apoidea). Scopolia, Ljubljana 42: 1-79.

GOUlson D., HANLey M. E., DARVILl B., Ellis J. S. \& KNIGHT M. E. 2005. Causes of rarity in bumblebees. Biological Conservation 122: 1-8.

Goulson D., LYE G. C. \& DaRviLl B. 2008. Decline and conservation of bumble bees. Annual Review Entomology 53: $191-208$.

GROMISZ M. 1995. O stanie krajowej hodowli pszczół I kierunkach jej rozwoju. Zakład Upowszechniania Postępu ISK, Skierniewice, $51 \mathrm{pp}$.

GUGLIA O. 1969. Einfuhrung Heinrich Friese (1860-1948) In: FRIESE H. (ed.), Die Bienen Europas (Apidae Europaeae). I-III. Edition Anastatica Amsterdamie, A. Asher \&. Co. III-XIV pp.

IUGA V. G. 1958. Hymenoptera Apoidea, Fam. Apidae, Subfam. Anthophorinae. In: Fauna Republici Populare Romine. Academia Republici Populare Romine, Bucuresti, $270 \mathrm{pp}$.

JANZON L.-A., SVENSSON B. G. \& ERLANDSSON S.. 1991. Catalogus Insectorum Succiae. Hymenoptera, Apoidea. Entomologisk Tidskrift 112: 93-99.

JoRgEnSEN L. 1921. Bier. Danmarks fauna 25: 1-264, G. E. C. Gads, Kobenhavn.

KLUK K. 1802. Zwierząt domowych i dzikich, osobliwie krajowych, historyi naturalney początki i gospodarstwo. Tom IV. O owadzie i robakach, Warszawa, $500 \mathrm{ss}+9$ rycin.

KosIoR A. 1987. Wpływ działalności gospodarczej na populacje trzmieli Bombus Latr. w Bieszczadach Zachodnich. Ochrona Przyrody 45: 239-262.

Kostor A., Celary W., Solarz W., Rasmont P., Fijal J., Król W., WitKowski Z. \& Iserbyt S. 2008. Long-term changes in the species composition and distribution of Bombini (Apidae) in Cracow since the mid 1850s. Annales de la Societé Entomologique de France (Nouvelle série) 44 (4): 393-407.

KOWALCZYK J. K. 1997. New localities of Sting wasp species (Hymenoptera: Aculeata) in Poland. Wiadomości Entomologiczne 16: 53-54. [In Polish with English summary]

MOUSEVICIUS V. 1995. A checklist of wild bee species of Lithuania with data to their distribution and bionomics. In: Jonaitis V. (ed.), New and Rare for Lithuania Insect Species. Institute of Ecology, Vilnius, pp. 7-145.

NoSkIEwICZ J. 1939-1948a. [Referaty z zebrań w roku 1948 Polskiego Związku Entomologicznego]: J. W. Szulczewski. 1947. Pól wieku spostrzeżeń nad stepowieniem Wielkopolski. Poznańskie Towarzystwo Przyjaciół Nauk, Prace Komisji Matematyczno-Przyrodniczej, Ser. B. X, 200-206, Poznań. Polskie Pismo Entomologiczne 18 (2-4): 438-439.

NoskIEWICZ J. 1939-1948b. [Referaty z zebrań w roku 1948 Polskiego Związku Entomologicznego]: J. W. Szulczewski. 1948. Blonkówki (Hymenoptera) Wielkopolskiego Parku Narodowego. Część 111. Pszczołowate (Apidae). Poznańskie Towarzystwo Przyjaciół Nauk, Prace monograficzne nad przyrodą Wielkopolskiego Parku Narodowego pod Poznaniem. 2: 71-90. Poznań. Polskie Pismo Entomologiczne 18 (2-4): 440.

OSYTSHNJUK A. Z. 1970. Bdzoli-Koletidi (Apoidea, Colletidae). Fauna Ukrainy, Kiev 12 (4): 5-158.

O'TOOLE C. 1993. Diversity of native bees and agroecosystems. In: LASALLE J. AND. GAULD 1. D (eds), Hymenoptera and biodiversity, pp. 169-196. Natural History Museum London and CAB International, Wallingford, UK,. 348 pp.

O'TOOLE C. 1994. Who cares for solitary bees? In: MATHESON A. (ed.), Forage for Bees in an Agricultural Landscape. International Bee Research Association, Cardif, UK, pp. 47-55.

O’TOOLE C. \& RAW A. 1993. Bess of the World. Blandford Press, London, 192pp.

PAGliano G. 1995. Hymenoptera Apoidea. In: MnNNELli A., RUFFo S., LA POSTA S. (eds), Checklist delle specie della fauna italiana, $25 \mathrm{pp}$. 
PAWLIKOWSKI T. 1987. Wplyw systemu gospodarowania na dzikie pszczolowate (Hymenoptera, Apoidea) w krajobrazie rolniczym. Acta Universitatis Nicolai Copernici Biologia 35: 153-167.

PEKKARINEN A. 1999. Oligolectic bee species and their decline in Finland (Hymenoptera: Apoidea). In: ELBERG K., MARTIN M. \& PEKKARINEn A. (eds), Proceedings of the $24^{\text {th }}$ Nordic Congress of Entomology, Tartu, Estonia, 1997, pp. 151-156. University of Tartu \& Estonian Naturalists' Society.

PEKKARINEN A., TERÃs L, VIRAMO J. \& PAATELA J. 1981. Distribution of bumblebees (Hymenoptera, Apidae: Bombus and Psiihyrus) in eastern Fennoscandia. Notulae Entomologicae 61: 71-89.

PESENKO YU. A., BANASZAK J., REDCHENKO V. G. \& CERRINIAK T. 2000. Bees of the family Halictidae (excluding Sphecodes) of Poland: taxonomy, ecology, bionomics. Wydawnictwo Uczelniane Wyższej Szkoly Pedagogicznej w Bydgoszczy, 348 pp.

PIDEK A. 1991. Trendy w ekonomice pasiek w latach 1970-88 na podstawie estymacji funkcji. Pszczelnicze Zeszyty Naukowe 35: 83-90.

PLEWKA T. 1995. Bombus semenoviellus Skor. - nowy dla Polski gatunek trzmiela. In: NowACKI J. (ed.), Materiaty Zjazdowe, 42 Zjazd Polskiego Towarzystwa Entomologicznego, 8-10. 09. 1995, Poznań, 37-38, Wydawnictwo Polskie Towarzystwo Entomologiczne, Poznań, 53 pp.

Rasmont P., Leclerco J., Jacob-Remacle A., Patly A. \& Gaspar Ch. 1993. The faunistic drift of Apoidea in Belgium. In: BRUNEAU E. (ed.), Bees for pollination. Commision of the European Communities, Brussels, pp. 65-87.

RASMONT P., EBMER A., BANASZAK J., VAN DER ZANDEN G. 1995. Hymenoptera Apoidea Gallica. Liste taxonomique des abeilles de France, de Belgique, de Suisse et du Grand-Duché de Luxembourg. Bulletin de la Société entomologique de France 100: 1-98.

Rasmont P. \& TERzo M. 1996. Les Apoides de la Gaule (Hymenoptera). In: MAURIN H., Gutbot R., LHONORE J.. Chabrol L., StBert J. M., GAUVOIT B. (eds), Inventaire et cartographie des invertebres comme contribution a la gestion des milieux naturels Franęais. Musem National d'Histoire Naturelle, Paris pp. 219-222.

RAZOWSKI J. (ed.) 1990-1997. Checklist of Animals of Poland. Vol. 1-5. Instytut Systematyki i Ewolucji Zwierząt PAN, Kraków, 158, 342, 217, 303, 260 pp.

SCHWARZ F., GUSENLEITNER P., WESTRICH P. \& DATHE H. 1996. Katalog der Bienen sterreichs, Deutschlands und der Schweiz (Hymenoptera, Apidae). Entomofauna. Zeitschrift für Entomologie, Suppl. 8, 398 pp.

SKOWRONEK W. 1997. Rasy pszczoły miodnej. Instytut, Sadownictwa i Kwiaciarstwa, Skierniewice, 22 pp.

SMISSEN VAN DER J. \& P. RASMONT. 1999. Bombus semenoviellus Skorikov 1910. eine für Westeuropa neue Hummelart (Hymenoptera: Bombus, Cullumanobombus). Bembix 13: 21-24.

SOKOŁOWSKI J. 1947. Wpływ oddrzewienia na stepowienie fauny Wielkopolski. In: WODZICZKO A. (ed.), Stepowienie Wielkopolski. I. Poznańskie Towarzystwo Przyjaciól Nauk, Prace Komisji Matematyczno-Przyrodniczej, B, 10 (4): 194-199.

SZULCZEWSKI J. W. 1947. Pół wieku spostrzeżeń nad stepowieniem Wielkopolski, In: WoDZICZKO A. (ed.), Stepowienie Wielkopolski. I. Poznańskie Towarzystwo Przyjaciól Nauk, Prace Komisji MatematycznoPrzyrodniczej, Ser. B, 10 (4): 200-206.

SZULCZEWSKI J. W. 1948. Błonkówki (Hymenoptera) Wielkopolskiego Parku Narodowego. 3: Pszczołowate (Apidae). Poznańskie Towarzystwo Przyjaciół Nauk, Prace monografíczne nad przyrodą Wielkopolskiego Parku Narodowego pod Poznaniem 2 (3): 71-90.

StOECKHERT F. K. 1933. Die Bienen Frankens (Hym., Apid.) Deutsche Entomologische Zeitschrift 1932: 1-294.

StoEckHERT F. K. 1954. Fauna Apoideorum Germaniae. Abhandlungen der Bayerischen Akademie der Wissenschaften 65: 1-87.

StraKa J., BOGUSCh P., PŘIdAL A. 2007. Apoidea: Apiformes (včely). Acta Entomologica Musei Nationalis Pragae, Suppl. 11: 241-299.

ŚWĘCICKI W. 2009. Dlaczego giną pszczoly? Przegląd Pszczelarski 2 (15): 16-21.

TORKA V. 1913. Die Bienen der Provinz Posen. Zeitschrift des Naturwissenschaftlichen Vereis Posen 20: 67-181.

TORKA V. 1933. Nachtrage zu meiner Veroffentlichung ber "Die Bienen der Provinz Posen". Deutsche Wissenschaftliche Zeitschrift für Polen 26: 83-94.

VIKBERG V. 1986. A checklist of aculeate Hymenoptera of Finland (Hymenoptera, Apocrita, Aculeata). Notulae Entomolgicae 66: 65-85.

WILDE J. 2009a. Varroa destructor a CCD i zapobieganie masowym ginięciom pszczól. Pszczelarstwo, 60 (3): $2-4$.

WILDE J. 2009b. Inne przyczyny masowego ginięcia pszczól. Pszczelarstwo 60 (4): 2-4.

WiLliams P. H. 1982. The distribution and decline of British bumblebee bees (Bombus Latr.). Journal of Apicultural Research 21 (4): 236-245.

WILLIAMS P. H. 1986. Environmental change and the distributions of British bumble bees (Bombus Latr.). Bee World 67 (2): $50-61$.

WLLIAMS P. H. 1989. Bumble bees and their decline in Britain. Central Association of Beekeepers, Ilford, UK, 15 pp.

WoDZiczKo A. (ed.) 1947. Stepowienie Wielkopolski. I. Poznańskie Towarzystwo Przyjaciół Nauk, Prace Komisji Matematyezno-Przyrodniczej, Ser. B, 10 (4): 137-235.

WRÓBLEWSKI R. 1991. Polskie pszczelarstwo, Zakład Narodowy im. Ossolińskich, Wrocław, 376 pp +170 rys.

ZAREBBA R. 1986. Puszcze, bory i lasy Polski. Państwowe Wydawnictwo Rolnicze i Leśne, Warszawa, 204 pp. 


\section{STRESZCZENIE}

[Przemiany fauny na przykladzie owadów zapylających (Hymenoptera: Apoidea, Apiformes)]

Na przykładzie Polski i innych krajów europejskich omówiono zagadnienie przemian fauny pszczół Apiformes, poczynając od czasów historycznych. Współczesne przemiany przedstawiono z uwzględnieniem różnych kierunków zmian: (a) spadku liczebności populacji lub zaniku niektórych gatunków (kurczenie się areałów) czy (b) wzrostu populacji lub ekspansji innych. Ukazano dynamiczny obraz fauny na tle zmian środowiska (teza o fluktuacjach). Postawiono postulat konieczności wspólczesnych kompleksowych badan zasobów fauny - zróżnicowania gatunkowego i zagęszczenia. 